\title{
STATE OPPORTUNITIES FOR ACTION: UPDATE OF STATES' COMBINEd HEAT AND POWER ACTIVITIES
}

\author{
Elizabeth Brown and R. Neal Elliott
}

October 2003

Report Number IE032

CAmerican Council for an Energy-Efficient Economy

1001 Connecticut Avenue, NW, Suite 801, Washington, D.C. 20036 (202) 429-8873 phone, (202) 429-2248 fax, http://aceee.org website 



\section{CONTENTS}

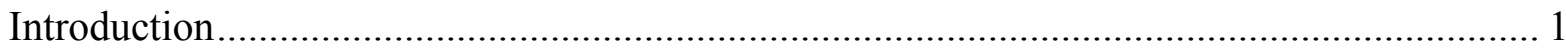

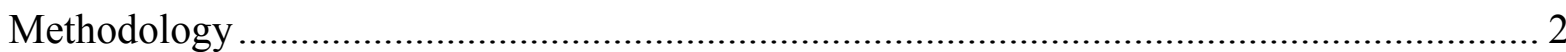

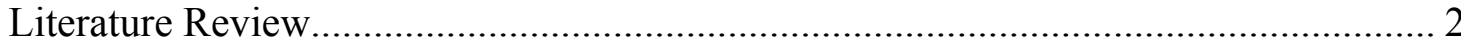

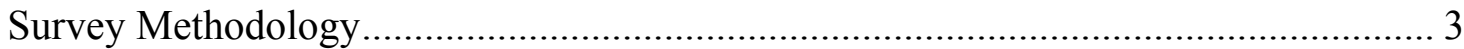

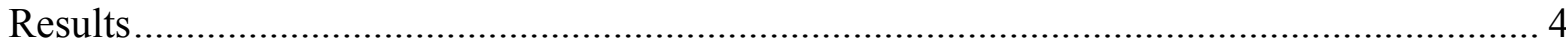

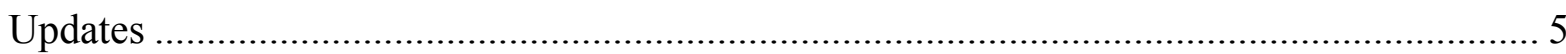

Notable Newcomers: Kentucky and New Hampshire ……….................................. 5

Continuing Progress......................................................................................... 5

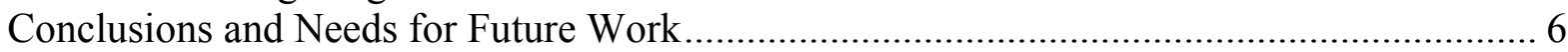

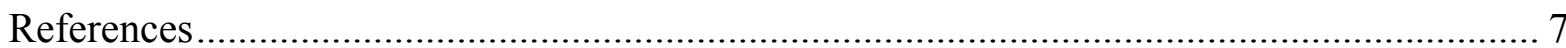

Appendix: State-by-State Activity Regarding CHP ………............................................ 11

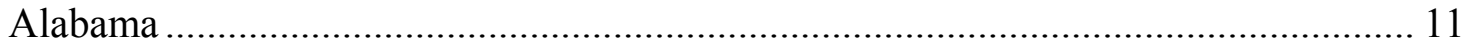

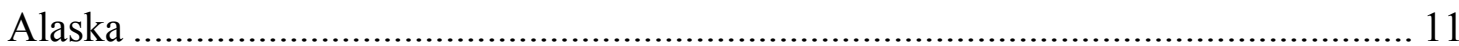

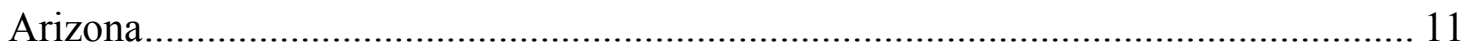

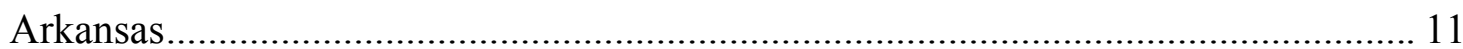

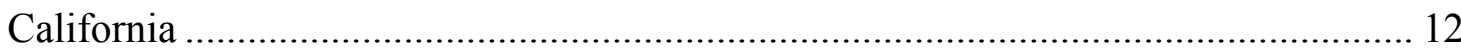

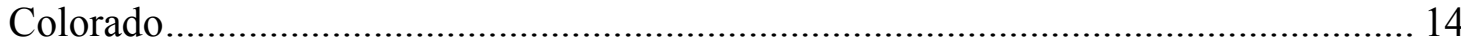

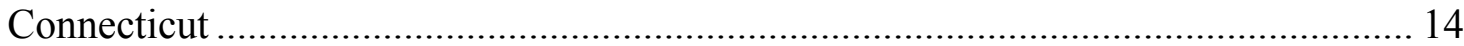

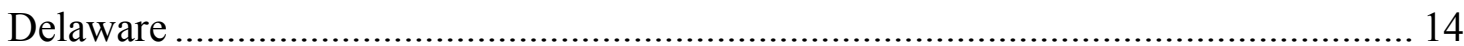

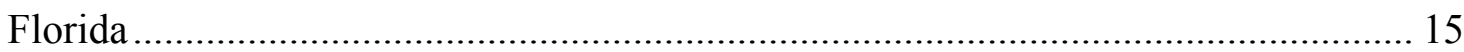

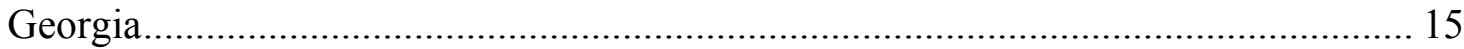

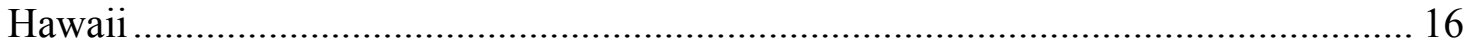

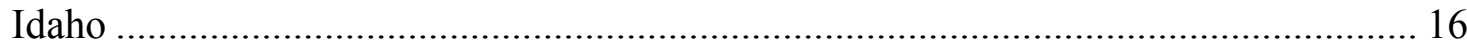

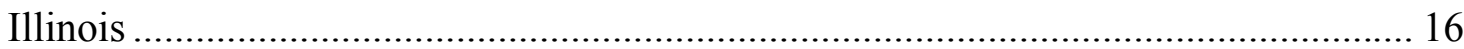

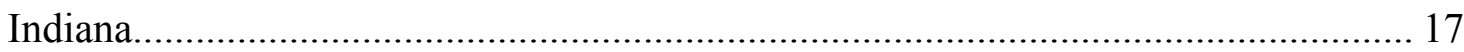

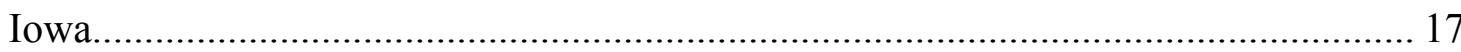

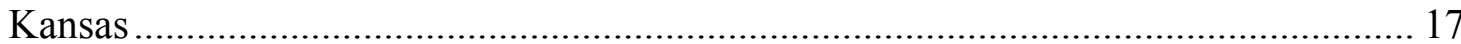

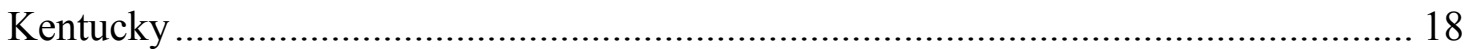

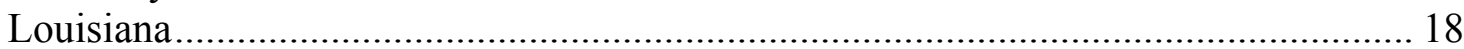

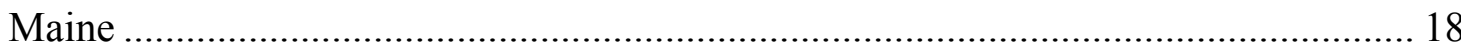

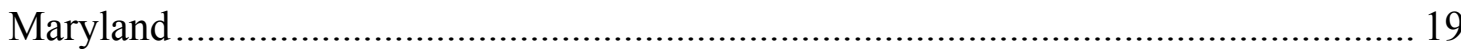

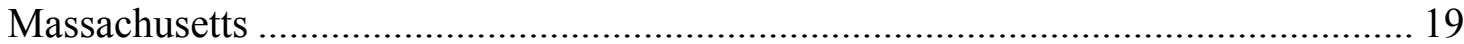

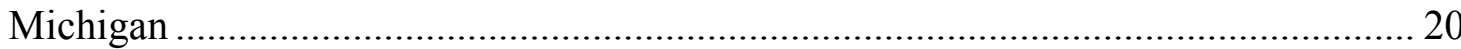

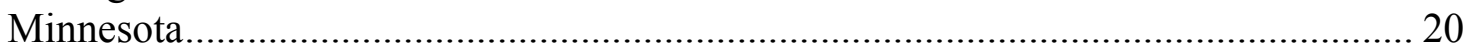

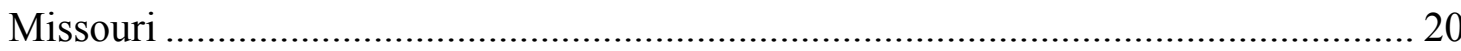

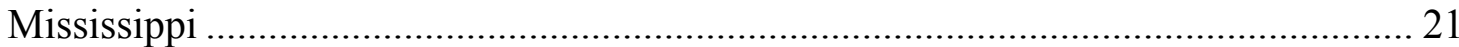

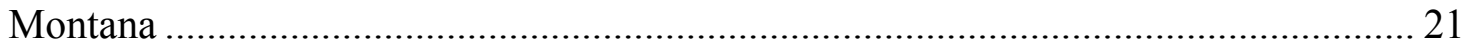

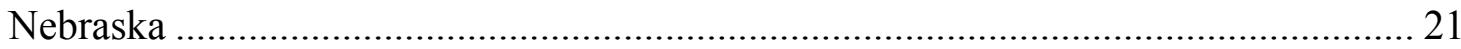

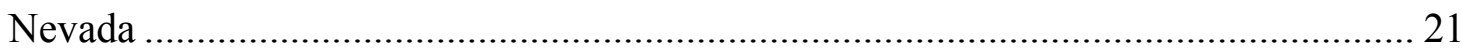

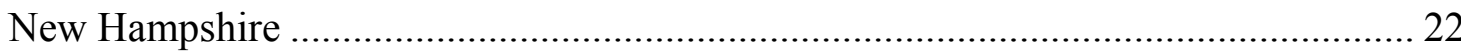

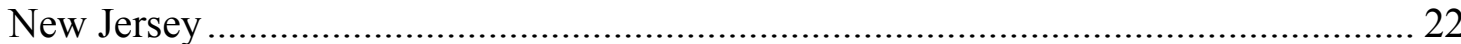

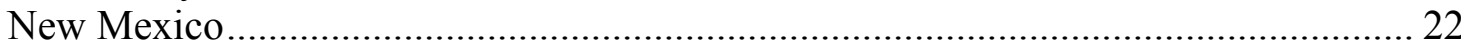

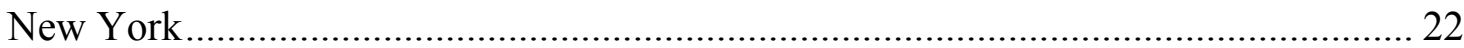

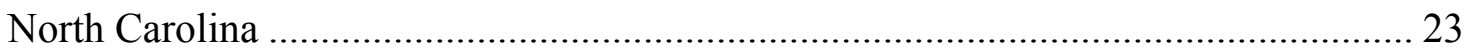




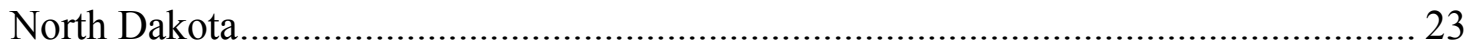

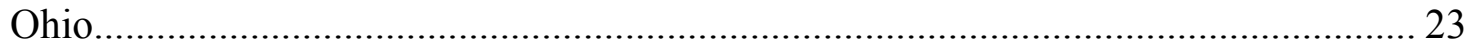

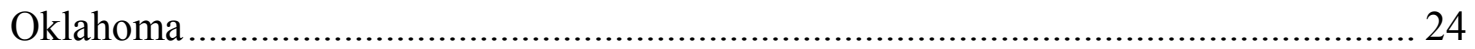

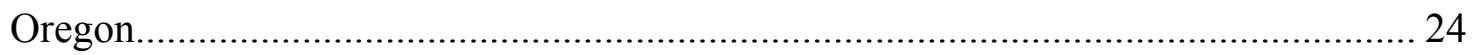

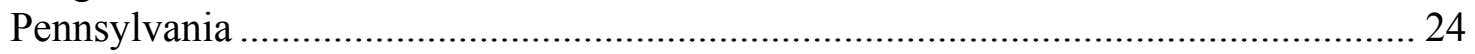

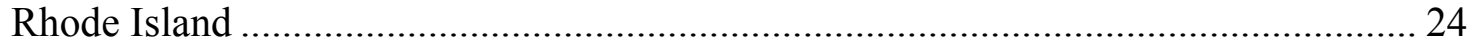

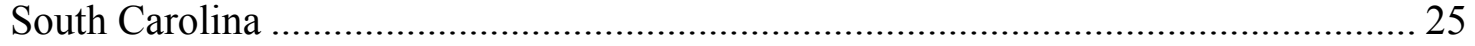

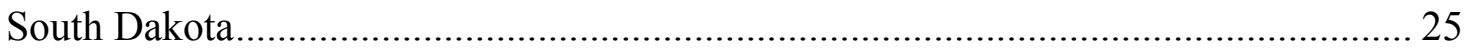

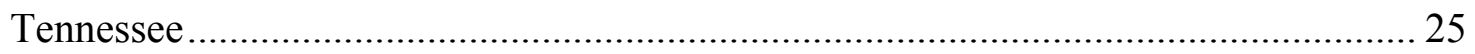

Texas

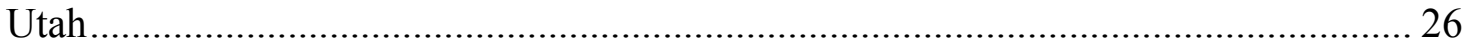

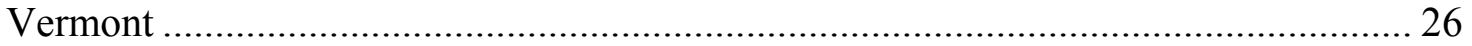

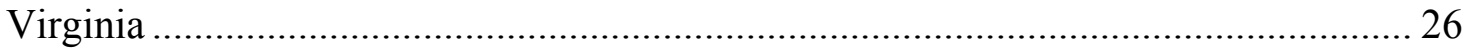

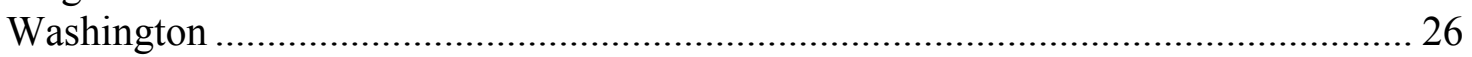

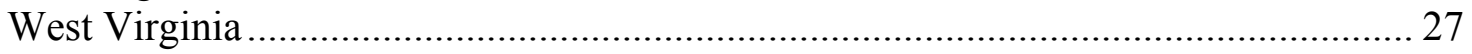

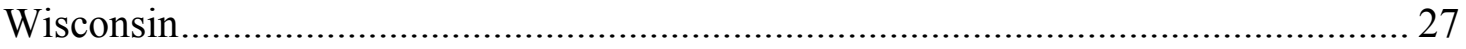

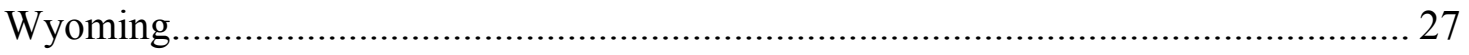

\section{ABSTRACT}

Combined heat and power (CHP) has been the focus of federal attention since the mid1990s. However, many of the market barriers to CHP are at the state level. As a sign of the maturing CHP market, a number of states are now undertaking activities to address barriers to CHP, and some states have begun to provide incentives to encourage the development of systems in their states.

This report brings up to date the review of state policies with regard to CHP that ACEEE completed in 2002. It describes the current activities of states with programs during the initial survey and also reviews new programs offered by states. 


\section{INTRODUCTION}

In 2002, ACEEE released a report detailing state legislative policies toward combined heat and power, which is available online at http://www.aceee.org/pubs/ieo22full.pdf. In the intervening year, there has been much activity on state, legislative, and regulatory fronts related to CHP. This activity is partially a result of the maturing of many state and regional advocacy networks. This report summarizes the newest developments in CHP state policy through June of 2003. In order to continue building a comprehensive listing, we also incorporates previously available information on legislation and regulation in the areas of interconnection, emissions standards, and financial incentives offered for CHP.

During the research for this report, we continued to encounter the existence of barriers to the installation of CHP that are not specifically covered here (for information on them, see Elliott, Shipley, and Brown 2003). These other barriers include complex rate design issues that are utility-based as opposed to state-based. Individual utility practices and policies will be covered by a forthcoming ACEEE report scheduled for release in early 2004. Moreover, because this report intends to educate the public about the difficulties of installing CHP, specifically not covered in this report are utility-owned CHP facilities and large investorowned utilities (IOUs).

This update of state policies toward CHP indicates a continued growth in knowledge at the state level of CHP, compared with the original study. While most states not taking legislative and regulatory action at the time of the first study have still not begun the process, states that were just beginning at the time of the earlier study have made significant progress. Figure 1 is a graphical representation of states that have had legislative and regulatory policies regarding CHP both in 2001 and 2003.

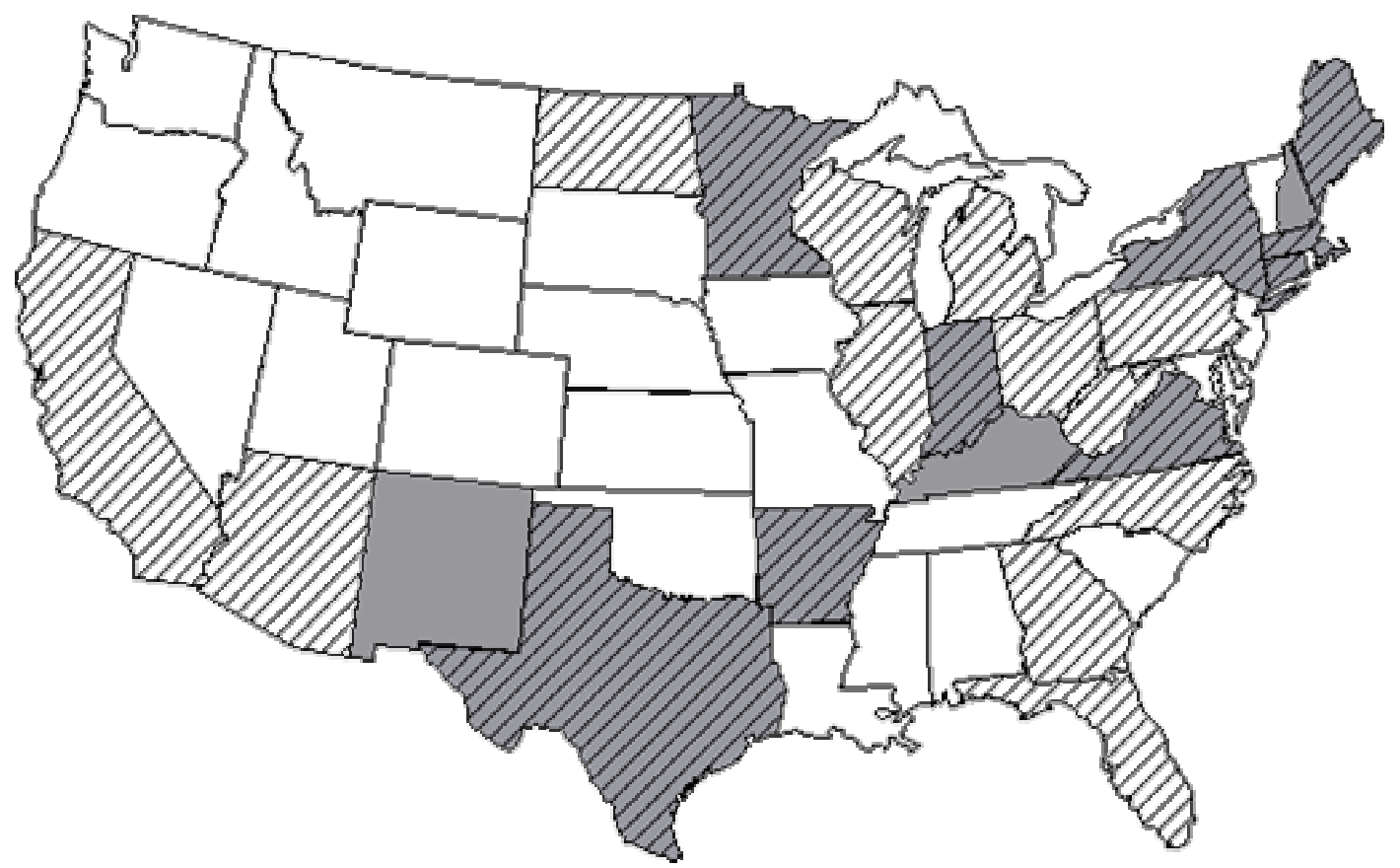

Figure 1: Map of United States Noting States with Policies in the Original Report (Diagonal Lines) and States that Have New Legislation or Regulation in this 2003 Report (Shaded Areas) 
This progress can be attributed to many factors. The current budget and fuel crises facing many states is causing them to look at distributed generation (DG) and CHP as a way to save financial as well as natural resources. The market has also grown since the original survey, putting more pressure on states to streamline processes and confront barriers. Deregulation is two years further along in many states, and resolution of DG issues such as interconnection and emissions regulations is imperative to a smooth transition to a deregulated market. Finally, the CHP advocacy community is growing and maturing, with the support of the National Energy Plan (NEPDG 2001).

Although there has been progress on the federal level regarding tax credits and Federal Energy Regulatory Commission (FERC) interconnection policies (FERC 2002), state action is still of great importance. States already have offices overseeing connection to the distribution grid and power production. Also, state legislators and offices know the needs of their states and the condition of the grids very well, so programs can be tailored to the needs of the states. Finally, states may already have programs or incentives (typically for photovoltaics or wind) that can act as the foundation for incentives for CHP. Clearly, state action that works in tandem with federal action would be the smoothest and quickest way to encourage installation of CHP facilities.

\section{METHODOLOGY}

\section{Literature Review}

In the process of updating this report, ACEEE updated the original literature review to include the newest reports and data regarding market barriers to CHP. Following is a description of the key literature sources that we drew upon in preparing this report.

The National Renewable Energy Laboratory (NREL) undertook significant work in the late 1990s to compile case studies on distributed energy projects in various locations around the country. This work included categorizing the barriers to a number of projects including several CHP projects (NREL 2000).

A significant amount of research has been published on net metering. All interconnections to the grid need some metering rule. Not all net metering rules apply to CHP facilities, but an excellent source of information on all state net metering laws is a table put together by Thomas Starrs in 1996 (Starrs 1996).

EFI/XENERGY, Inc. produced a listing of incentives for distributed energy resources for all the states. This report covered all financial incentives and loan programs for renewable and efficient technologies. The most helpful aspect of this report was its level of detaildown to the individual utility for most states (EFI/XENERGY, Inc. 2001).

A small but important body of research has been published regarding utility interconnection fees (Ferrey 2000). Often, these stand-by and exit fees are the determining barriers for potential projects. These charges are problems unique to deregulating and deregulated states, but as more states move to open electricity markets, so do the 
complications arising from these fees. In order to sort out the technical and market potential for CHP nationwide, the U.S. Department of Energy's Energy Information Administration commissioned Onsite Sycom Energy Corporation to review both the commercial and industrial sectors. Its report describes both current capacity and potential in all the states (Onsite Sycom 2000).

In 2003, the Northeast Midwest Institute released a report reviewing state policies regarding output-based standards (Freedman and Watson 2003). This report included the status of electricity restructuring in the states, as well as the status of output-based standards on a state and federal level. Because the NEMW report is a comprehensive review of emissions laws and regulations regarding output-based standards, they are not heavily emphasized here.

\section{Survey Methodology}

ACEEE conducted the previous survey to form a comprehensive reference work for policy-makers to look to for ideas and information regarding CHP policies in their states. To gather information from states, the researchers contacted the public utility commissions (PUC) and the state energy office (SEO) in each state. Once a suitable contact in each office was found, phone or e-mail interviews were conducted using the questions summarized in Table 1.

Table 1. Summary of Preliminary Questions for PUCs and SEOs

\section{Questions for State Utility Commissions}

Does your state utility commission have any policies regarding CHP installation (e.g., interconnection to the grid)?

Does your state have any emissions regulations regarding CHP?

Do you know of any companies that have attempted an installation?

Are there any special rates or other provisions available for CHP or clean power?

\section{Questions for State Energy Offices}

Are there any state regulations for the installation of CHP?

Emissions

Interconnection

Rate design

Siting regulations

Is there a state incentive for CHP installation?

Tax credits

Project co-funding or loans

The preliminary questions led to follow-up calls and Internet research, leading to a more complete picture of the legislative and regulatory framework in each state. As the study progressed, it was determined that contacting the state environmental protection agencies was the best approach for determining if the states had special emissions permitting opportunities for CHP. These agencies were then contacted. 
For this follow-up report, each of the contacts in the states were re-contacted via e-mail and asked to determine if the information from the last report was accurate, or if any new legislation/regulation had been put in place. Accompanying the survey was an Internet- and phone-search based on information gathered in the first survey.

\section{RESULTS}

The data were combined and compiled on a state-by-state basis. Table 2 is an updated version of the original table - states that were updated in this report are shaded. (For a detailed listing of the state legislation and regulation, please see the appendix.) The first column indicates the availability of a state-level incentive for CHP. The second column indicates (where applicable) the existence of interconnection standards in the state and which agency has them. If no standardized interconnection agreement system exists in the state through either the public utility commission ("P") or state ("S"), the utility companies ("U") determine the interconnection rules on an individual basis. The final column represents the

Table 2. Summary Results for State Activities

\begin{tabular}{|c|c|c|c|}
\hline State & $\begin{array}{l}\text { Financial } \\
\text { Incentives }\end{array}$ & $\begin{array}{c}\text { Installation/ } \\
\text { Interconnection }\end{array}$ & $\begin{array}{c}\text { Emissions } \\
\text { Regulations }\end{array}$ \\
\hline Arizona & $\mathrm{N}$ & $P^{*}, U$ & $\mathrm{~N}$ \\
\hline Arkansas & $\mathrm{N}$ & $\mathrm{P}$ & $\mathrm{N}$ \\
\hline California & $\mathrm{N}$ & $S$ & $\mathrm{~S}$ \\
\hline Connecticut & $\mathrm{N}$ & $\mathrm{P}^{*}, \mathrm{U}$ & $S$ \\
\hline Delaware & $\mathrm{N}$ & $P^{\wedge}, U$ & $\mathrm{~N}$ \\
\hline Florida & $\mathrm{N}$ & $\mathrm{S}^{\wedge}, \mathrm{U}$ & $\mathrm{N}$ \\
\hline Georgia & $\mathrm{N}$ & $\mathrm{S}^{\wedge}, \mathrm{U}$ & $\mathrm{N}$ \\
\hline Hawaii & $S$ & $\mathrm{U}$ & $\mathrm{N}$ \\
\hline Illinois & $\mathrm{N}$ & $\mathrm{P}^{*}, \mathrm{U}$ & $\mathrm{N}$ \\
\hline Indiana & $S$ & $\mathrm{P}^{*}, \mathrm{U}$ & $\mathrm{N}$ \\
\hline Kentucky & $\mathrm{N}$ & $\mathrm{P}^{\wedge}, \mathrm{U}$ & $\mathrm{N}$ \\
\hline Maine & $\mathrm{N}$ & $\mathrm{P}^{*}, \mathrm{U}$ & $\mathrm{N}$ \\
\hline Massachusetts & $\mathrm{N}$ & $\mathrm{P}^{*}, \mathrm{U}$ & $\mathrm{S}^{*}$ \\
\hline Michigan & $S$ & $S$ & $\mathrm{~N}$ \\
\hline Minnesota & $\mathrm{N}$ & $\mathrm{P}^{*}, \mathrm{U}$ & $\mathrm{S}^{*}$ \\
\hline New Hampshire & $\mathrm{N}$ & $\mathrm{U}$ & $\mathrm{S}^{* \Lambda}$ \\
\hline New Mexico & $\mathrm{N}$ & $\mathrm{P}^{* \wedge}, \mathrm{U}$ & $\mathrm{N}$ \\
\hline New York & $\overline{S^{\wedge}}$ & $\mathrm{P}$ & $\mathrm{S}^{*}$ \\
\hline North Carolina & $S$ & $U$ & $\mathrm{~N}$ \\
\hline North Dakota & $\mathrm{N}$ & U & $\mathrm{N}$ \\
\hline Ohio & $\mathrm{N}$ & $\mathrm{P}$ & $\mathrm{N}$ \\
\hline Pennsylvania & $\mathrm{N}$ & $\mathrm{P}$ & $\mathrm{S}^{*}$ \\
\hline Texas & $\mathrm{N}$ & $\mathrm{P}$ & $\mathrm{S}$ \\
\hline Virginia & $\mathrm{N}$ & $\mathrm{P}^{*}, \mathrm{U}$ & $\mathrm{N}$ \\
\hline West Virginia & $\mathrm{N}$ & $\mathrm{P}$ & $\mathrm{N}$ \\
\hline Wisconsin & $\mathrm{P}$ & $\mathrm{P}^{*}, \mathrm{U}$ & $\mathrm{N}$ \\
\hline
\end{tabular}

Key: $\mathrm{N}=$ no special considerations for $\mathrm{CHP} ; \mathrm{S}=$ state; $\mathrm{P}=$ public utility commission or equivalent; $\mathrm{U}=$ utility; ${ }^{*}=$ in progress; ${ }^{\wedge}=$ offers standards to a certain size (or type-NOT CHP) of distributed generation 
emissions regulations regarding CHP in the state. All the states have pollution regulations for most power-producing facilities (with the exception of emergency generators), but not many of these regulations take into consideration the increased efficiency of CHP by using output-based standards. States that do take this into consideration are marked in the last column with an "S." States not listed in Table 2 fall into the category of "NUN": no statelevel financial incentives ("N"); the utility ("U") regulates interconnections to the grid; and there are no state-level special emissions rules for CHP ("N"). For more in-depth information, please refer to the appendix, where the data is organized by state.

\section{UPDATES}

This section highlights the legislative and regulatory updates that have a large impact or are potential models for other states. States that did not have policies or regulations in the first survey are particularly of interest, as they may build off previous state action. These states include Kentucky and New Hampshire. States that were represented in the first report that have continued to create new and revise previous legislation are also highlighted. These states are Arkansas, Connecticut, Indiana, Maine, Massachusetts, Minnesota, New York, and Virginia.

\section{Notable Newcomers: Kentucky and New Hampshire}

Net metering policies are generally the forerunner of structured DG (therefore CHP) policies within states because answering questions critical to net metering often opens up a variety of questions that impact the role of DG in the state. The Kentucky PSC issued an order to utilities in 2002 to allow net metering for renewable energy projects of small size. While many states (Starrs 1996) allow net metering policies for renewables, Kentucky draws special attention because this order is a pilot program to determine the fate of net metering. The success or failure of this program will be an important factor in deciding the fate of net metering, and CHP, in the state.

New Hampshire is representative of the New England states that are creating a nitrogen oxides (NOx) budget program or state multi-pollutant strategy. CHP is impacted by the creation of a NOx budget strategy because half the fuel in CHP is used to create two forms of usable energy: electricity and heat (generally in the form of steam). This decreases the emission of NOx substantially, and increases the economic viability of CHP systems in the state. Connecticut and Massachusetts are also creating NOx budgets or trading schemes.

\section{Continuing Progress}

Minnesota and Massachusetts have taken large steps forward in creating interconnection language that is fair and balanced for all stakeholders. Both states reported that interconnection proceedings were underway in 2002, and both have reported that the respective utility commissions are now reviewing the reports. In Massachusetts, over 50 stakeholder groups met for over a year to come to a compromise on technical and market interconnection issues. Both of these states exemplify the importance of successful 
stakeholder interaction in creating a workable agreement. These processes have the added benefit of connecting the DG and CHP communities.

The state of Indiana offers a state-based incentive for DG, specifically including CHP. The DG Grant Program (DGGP) offers grants for renewable energy projects and CHP projects from $\$ 5,000$ to $\$ 30,000$. The goal of the program is to promote non-centralized generation as a viable, clean resource. The projects must have a thermal efficiency of 30 percent or greater and contribute at least $20 \mathrm{~kW}$ baseload for the facilities they serve. An interesting aspect of this program is that it is aimed at commercially proven technologies, not at emerging technologies. In an environment where technological questions are greatly reduced, a focus on market barriers to these technologies may challenge Indiana to confront emissions and utility barriers. More information on Indiana's program can be found at http://www.in.gov/doc/businesses/PDFs/DGGPguidelines.pdf.

\section{CONCluSions AND NEEDS FOR FUtURE WORK}

This report updates state approaches to promoting the use of CHP by categorizing programs and policies related to CHP by state. Since the original research was done in 2002, three states have begun work to reduce market CHP barriers at the state level, and many other states have made progress in breaking down barriers. ACEEE found that there are a few states that have made significant progress and can serve as models. One potential model for state incentives is the Indiana Distributed Generation Grant Program mentioned above.

Because of the continuously changing environment of state regulation and legislation, the information in this report will need to be continually updated. Creating a database of state incentives and approaches to barriers that is highly accessible to both states and designers would create a single access point for CHP information.

Another important finding is that many of the interconnection barriers exist at the individual utility level, not the state. Many of the people contacted for this report indicated that it was the utility that was discouraging CHP installation. A systematic survey is underway to catalogue major utility policies relative to CHP.

While the opportunities for electricity savings through $\mathrm{CHP}$ are large, realizing this opportunity requires breaking down the barriers to CHP, following the lead of key states, and building on their progress. Although this update suggests that states are continuously progressing at identifying and overcoming barriers, significant state work remains to be done, in particular among states that have no CHP-related programs or policies. This work needs to coordinate with federal and utility activity to create an atmosphere conducive to CHP and electricity savings. 


\section{REFERENCES}

[Arkansas PSC] Arkansas Public Service Commission. 2002. Net Metering Rules. Little Rock, Ark: Arkansas Public Service Commission.

Assembly of Arkansas. 2001. "The Arkansas Renewable Energy Development Act of 2001." Ark. Code Ann. §23-18-601 through §23-18-604. Little Rock, Ark.: Assembly of Arkansas.

Barnes, J. (Kansas Natural Resources Council). 2002. Personal communication with Elizabeth Brown. June.

Benson, C. (Arkansas Public Service Commission). 2003. Personal communication with Elizabeth Brown. June.

Bozzo, V. (New Jersey Board of Public Utilities). 2002. Personal communication with Kalon Scott. April.

Brown, E., H. Sachs, P. Quinlan, and D. Williams. Tax Credits for Energy Efficiency and Green Buildings: Opportunities for State Action. ACEEE-E021. Washington, D.C.: American Council for an Energy-Efficient Economy.

Colson, L. (Florida Public Service Commission). 2002. Personal communication with Elizabeth Brown. June.

Cuttica, J. (University of Chicago). 2002. Personal communication with Kalon Scott. June.

[DGC] Distributive Generation Interconnection Collaborative. 2003a. "Proposed Standard for Interconnecting Distributed Generation in Massachusetts." http://www.dg.raabassociates.org/Articles/DG\%20Report.Final.doc. Boston, Mass.: Distributive Generation Interconnection Collaborative.

— 2003b. "Tariff to Accompany Proposed Standard for Interconnecting Distributed Generation in Massachusetts." http://www.dg.raabassociates.org/Articles/ Tariff_Rev3_5.15.doc. Boston, Mass.: Distributive Generation Interconnection Collaborative.

Dillard, J. (Delaware Public Service Commission). 2002. Personal communications with Kalon Scott and Elizabeth Brown. April-June.

EFI/XENERGY, Inc. 2001. 2001 Guidebook of Funds and Incentives for Distributed Energy Resources. Burlington, Mass.: EFI//XENERGY, Inc.

Elliott, R.N., A.M. Shipley, and E. Brown. 2003. CHP Five Years Later: Federal and State Policies and Programs Update. ACEEE-IE031. Washington, D.C.: American Council for an Energy-Efficient Economy. 
[EnergyWise] Florida Energy 2020 Study Commission. 2001. Florida...EnergyWise: A Strategy for Florida's Energy Future. The Final Report of the Florida Energy 2020 Study Commission. Tallahassee, Fla: Florida Energy 2020 Study Commission.

[ENN] Environmental News Network. 2001. Easing the Way for Efficient Combined Heat and Power Generators. http://www.enn.com/news/enn-stories/2001/10/10182001/ s_45301.asp. Berkeley, Calif.: Environmental News Network.

[FERC] Federal Energy Regulatory Commission. 2002. Standardization of Small Generator Interconnection Agreements and Procedures, Advance Notice of Proposed Rulemaking. Docket No. RM02-12-000. Washington, D.C.: Federal Energy Regulatory Commission.

Ferrey, S. 2000. "No Exit: Shaping the New Electricity Market." The Electricity Journal, 13 (5).

Free, J. (Alabama Public Service Commission). 2003. Personal communication with Elizabeth Brown. June.

Freedman, S. and S. Watson. Output Based Emissions Standards: Advancing Innovative Technologies. Washington, D.C.: The Northeast Midwest Institute.

[GCE] Georgia Clean Energy. 2001. Summary of SB 93: The Cogeneration and Distributed Generation Act of 2001. http://www.cleanenergy.ws/fact_sheets/ sb93_sum.html. Atlanta, Ga.: Georgia Clean Energy.

Gordes, J. (Environmental Energy Solutions). 2002. Personal communication with Elizabeth Brown. June.

Haase, J. (State of Minnesota, Department of Commerce, Energy Division). 2002. Personal communication with Kalon Scott. April.

[IREC] Interstate Renewable Energy Council. 2001. Connecting to the Grid: Interconnection Newsletter. http://www.irecusa.org/articles/static/1/991800564_987096476.html. April.

Keene, Barbara (Arizona Corporation Commission). 2002. Personal communications with Elizabeth Brown and Kalon Scott. April-June.

[Mass. DEP] Massachusetts Department of Environmental Protection: Bureau of Waste Prevention, Department of Planning and Evaluation. 2003. Background Document and Technical Support for Public Hearings on Proposed Amendments to 310 CMR 7.00 et seq.:310 CMR 7.28 "NOx Allowance Trading Program." http://www.state.ma.us/dep/bwp/daqc/files/backgrnd.doc. Boston, Mass.: Massachusetts Department of Environmental Protection.

Mayer, M. (Connectiv Power). 2002. Personal communication with Elizabeth Brown. June. 
McGee, D. (Louisiana Department of Natural Resources). 2002. Personal communication with Kalon Scott. May.

[Minn. DOC] Minnesota Department of Commerce. 2003. Report on Distributed Generation Technical Standards and Tariffs. Minneapolis, Minn.: Minnesota Department of Commerce.

[NEPDG] National Energy Policy Development Group. 2001. National Energy Policy. Washington, D.C.: U.S. Government Printing Office.

[NREL] National Renewable Energy Laboratory. 2000. Making Connections: Case Studies of Interconnection Barriers and Their Impact on Distributed Power on Projects. NREL/SR-200-28053. Golden, Colo.: National Renewable Energy Laboratory.

[NY PSC] New York Public Service Commission. 2001. 99-E-1470 Ongoing Proceeding on Motion of the Commission as to the Reasonableness of the Rates, Terms, and Conditions for the Provision of Electric Standby Service. Albany, N.Y.: New York Public Service Commission.

Olivier, P. (Entergy, Inc.). 2002. Personal communication with Elizabeth Brown. April.

Onsite Sycom. 2000. The Market and Technical Potential for Combined Heat and Power in the Industrial Sector. Washington, D.C.: Onsite Sycom.

[PSCW] Public Service Commission of Wisconsin. 2001. Development of Electric Generation. http://www.psc.wi.gov/electric/cases/electgen/electgen.htm. Madison, Wisc.: Public Service Commission of Wisconsin.

Quinlan, M. (Connecticut Department of Utility Commissioners). 2002. Personal communication with Elizabeth Brown. June.

Rhueame, T. (Arkansas Department of Environmental Quality, Air Division). 2002. Personal communication with Elizabeth Brown. June.

Rogers, E. (Indiana Department of Commerce, Energy and Recycling Office). 2003. Personal communication with Elizabeth Brown. June.

Shaw, J. (Kentucky Public Service Commission). 2003. Personal communication with Elizabeth Brown. June.

Smith, S. (New York State Research and Development Authority). 2002. Personal communication with Elizabeth Brown. June.

Starrs, Thomas J. 1996. "Net Metering: New Opportunities for Home Power." Renewable Energy Policy Project. Issue Brief \#2. Updated at http://www.eren.doe.gov/greenpower/netmetering/nmtable.shtml. 
Surovik, M. (California Air Resources Board). 2002. Personal communication with Elizabeth Brown. June.

Swim, D. (Legal Environmental Assistance Foundation). 2002. Personal communication with Elizabeth Brown. June.

[TNRCC] Texas Natural Resources Conservation Commission. 2001. Air Quality Standard Permit for Electric Generating Units. Austin, Tex.: Texas Natural Resources Conservation Commission.

Wentz, C. (New Mexico Energy, Minerals, and Natural Resources Department). 2003. Personal communication with Elizabeth Brown.

Weston, R. (Regulatory Assistance Project). 2002. Personal communication with Elizabeth Brown. June.

Worden, M. (New York Public Service Commission). 2002. Personal communication with Elizabeth Brown. June.

Young, G. (Kentucky Division of Energy). 2003. Personal communication with Elizabeth Brown. June. 


\title{
APPENDIX: State-by-State ACTIVITy Regarding CHP
}

\author{
Alabama \\ State-Level Financial Incentives \\ None \\ Interconnection Provisions/Net Metering \\ None (Free 2003) \\ Emissions Regulations/Rules Specific to CHP \\ None
}

\begin{abstract}
Alaska
State-Level Financial Incentives

None

Interconnection Provisions/Net Metering

None

Emissions Regulations/Rules Specific to CHP

None
\end{abstract}

\section{Arizona}

\section{State-Level Financial Incentives}

None

\section{Interconnection Provisions/Net Metering}

In 1999, the Arizona Corporation Commission (ACC) formed a DG Working Group to investigate DG and interconnection in the state. The working group produced a final report for the ACC that summarized the next steps for mainstreaming DG in Arizona. The report can be found at http://www.cc.state.az.us/meetings/minutes/dgirpt7.pdf. Since its publication, however, the ACC has not followed up on any of the suggestions (Keene 2002).

ACC runs a program that allows net metering for cogeneration systems less than $100 \mathrm{~kW}$. Net energy is purchased at avoided cost, and the program applies to all IOUs and Rural Electric Cooperatives (Starrs 1996).

Emissions Regulations/Rules Specific to CHP

None

Arkansas

\section{State-Level Financial Incentives}

None (Benson 2003)

\section{Interconnection Provisions/Net Metering}

In 1983, the Arkansas Public Service Commission (Arkansas PSC) published its interconnection rules, closely following the federal Public Utility Regulatory Policy Act (PURPA) rules. Arkansas's rules can be viewed at http://170.94.29.3/rules/cogeneration_rules.pdf. 
In 2001, Arkansas passed a net metering rule through Act 1781, "The Arkansas Renewable Energy Development Act of 2001" (Assembly of Arkansas 2001). The bill directed the Arkansas PSC to carryout the rulemaking process, which was completed in 2002 (Arkansas PSC 2002). This net metering rule prescribed a relatively simple interconnection agreement, and that the utility must maintain the net metering facility's original rate structure. However, the facility does not receive compensation for transferring to the grid more electricity than is used by the facility. The restriction on this is $25 \mathrm{~kW}$ for residential uses and $100 \mathrm{~kW}$ for commercial and agricultural uses.

Entergy, a utility that covers three-quarters of the state usage, has an interconnect tariff based on the federal North American Electric Reliability Council (NERC) planned tariff (Olivier 2002).

\section{Emissions Regulations/Rules Specific to CHP}

None (Rhueame 2002)

\section{California}

\section{State-Level Financial Incentives}

The CPUC runs the Self-Generation Incentive Program, which offers incentives to clean DG up to 1 megawatt (MW). See

http://www.pge.com/selfgen/pdf/Program_Handbook_R2_Final_05-06-02.pdf.

\section{Interconnection Provisions/Net Metering}

CHP is covered under "Rule 21"-DG tariffs by the California Public Utility Commission.

Rule 21 can be found at

http://www.energy.ca.gov/distgen/interconnection/california_requirements.html. California was the first state to have a standard practice for interconnection for every utility in the state's jurisdiction.

\section{Emissions Regulations/Rules Specific to CHP}

Set by local air quality districts.

In 2000, Senate Bill 1289 was signed into law requiring the California Air Resources Board to implement a certification program for DG units that are exempt from local air district permits. Exempt units are typically smaller units, but not emergency generators. The 2003 standards have a CHP provision that allows for a minimum $60 \%$ efficiency and slightly higher emissions standards to balance the offset in emissions that CHP provides (Surovik 2002). Further details can be found at http://www.arb.ca.gov/energy/dg/dg.htm.

\section{Other Barriers or Incentives for CHP}

The California Energy Commission (CEC) has made removing barriers to small generators a priority. This is made evident by the Distributed Energy Strategic Plan, which can be found at http://www.energy.ca.gov/distgen/strategic/strategic_plan.html.

CEC exempted clean DG from utility exit fees in June of 2003 through the proceeding R0201011. 


\section{Colorado}

\section{State-Level Financial Incentives}

None

\section{Interconnection Provisions/Net Metering}

No standard interconnection requirement. Net metering for renewable energy sources.

\section{Emissions Regulations/Rules Specific to CHP}

None

\section{Connecticut}

\section{State-Level Financial Incentives}

None

\section{Interconnection Provisions/Net Metering}

Connecticut has no standardized provisions for interconnection aside from the PURPA qualifying facility (QF) guidelines. Facilities that are not QFs under PURPA negotiate with the utility on an individual basis. The Department of Public Utility Commissioners will issue a report that will announce that they will be starting work on interconnection standards (Quinlan 2002).

\section{Emissions Regulations/Rules Specific to CHP}

The Connecticut Department of Environmental Protection's Air Quality Division was involved in the design of the Regulatory Assistance Project (RAP) output-based standards for DG.

In 2002, the DEP revised the air emission permit programs to change the way "potential to emit" is defined. Several other definitional changes were made to come in line with the federal new source review program.

\section{Other Barriers or Incentives for CHP}

It is possible that the largest barrier to grid interconnection in the state is the lack of a model for utilities to follow regarding interconnection (Gordes 2002).

\section{Delaware}

\section{State-Level Financial Incentives}

Delaware does not offer a rebate for CHP, but Connectiv Power's Delaware Energy Alternatives Program offers a rebate for renewable technology. This program could be viewed as a precedent for a CHP rebate program in Connectiv's territory. More information on this program can be found at http://www2.state.de.us/publicadvocate/dpa/html/self_gen.asp.

\section{Interconnection Provisions/Net Metering}

Generators less than $1,000 \mathrm{~kW}$ that seek interconnection must follow the Connectiv Technical considerations. These are found at http://www2.state.de.us/publicadvocate/dpa/html/self_gen/self_gen_tech.doc. Delaware does not have interconnection standards for facilities over $1,000 \mathrm{~kW}$. Rates, terms, and conditions for these facilities are at the discretion of the customer and the utility. Disputes can be brought to the commission - in the past, none have been notable (Dillard 2002). Connectiv 
Power, Delaware's primary utility, asserts that it attempts to follow the PJM interconnection standards when considering large-scale CHP in its Delaware territory (Mayer 2002).

\section{Emissions Regulations/Rules Specific to CHP}

None

\section{Other Barriers or Incentives for CHP}

Delaware offers net metering for renewable energy projects under $25 \mathrm{~kW}$ - this could be viewed as a precedent for a CHP program.

\section{Florida}

\section{State-Level Financial Incentives}

There is no state-level financial incentive for cogeneration.

\section{Interconnection Provisions/Net Metering}

Florida offers an interconnection standard for qualifying QFs under PURPA and a small photovoltaic generation standard. The Florida PSC saw no reason to further any interconnect standards in the state and non-QF facilities are to coordinate with the utility in the service area (Colson 2002).

\section{Emissions Regulations/Rules Specific to CHP}

There are no specific emissions rules for CHP. All power generation facilities over $75 \mathrm{~kW}$ need to undergo the same siting procedure outlined in Statute 403 from the 2001 legislative session. This statute can be found at http://www.leg.state.fl.us/Statutes/index.cfm?App_mode=Display_Statute\&URL=Ch0403/p art02.htm\&StatuteYear $=2001 \&$ Title $=\% 2 \mathrm{D} \% 3 \mathrm{E} 2001 \% 2 \mathrm{D} \% 3 \mathrm{EChapter} \% 20403 \% 2 \mathrm{D} \% 3 \mathrm{EPart}$ $\% 20$ II. The 403 statute requires that facilities over $75 \mathrm{~kW}$ have a "need determination" and in order to receive one the facilities must have a contract with a utility. Because of utilityperceived drawbacks of cogeneration, utilities may deny the contract as a barrier to cogeneration facilities (Swim 2002).

\section{Other Barriers or Incentives for CHP}

The Florida governor's office commissioned a group to outline possibilities for Florida's energy future. This committee released a report that identified DG as a priority and suggested to the governor that the PSC actively pursue dismantling the inherent barriers (EnergyWise 2001).

\section{Georgia}

\section{State-Level Financial Incentives}

None

\section{Interconnection Provisions/Net Metering}

In 2001, the legislature enacted the "Cogeneration and Distributed Energy Act," which can be found at http://www2.state.ga.us/Legis/2001_02/sum/sb93.htm. This bill allows for small residential $(<10 \mathrm{~kW})$ and commercial $(<100 \mathrm{~kW})$ facilities to interconnect and receive net metering payments from the utility (GCE 2001). 


\section{Emissions Regulations/Rules Specific to CHP}

None

\section{Hawaii}

\section{State-Level Financial Incentives}

HB 175 offers a 4\% tax credit for technology infrastructure renovation costs. The language is written in such a way that it includes CHP.

For co-funding and loans, the state of Hawaii offers revenue bonds for independent power producers. More information can be found at http://www.capitol.hawaii.gov/hrscurrent/Vol01_Ch001-042/hrs039a/HRS_39A.htm.

There was an attempt at passing a bill that would allow faster depreciation of CHP, but the bill was not heard by the legislature.

\section{Interconnection Provisions/Net Metering}

Hawaii's four utilities set the interconnection standards. Smaller utilities work on a case-bycase basis.

Hawaii did consider a bill in the 2001 legislative session that would have directed the Hawaii PUC to lift barriers to interconnection. The finance committee did not hear this bill.

Hawaii offers net metering for small renewable projects, but not CHP.

\section{Emissions Regulations/Rules Specific to CHP}

None

Idaho

State-Level Financial Incentives

None

Interconnection Provisions/Net Metering

Interconnections and rates are done on a case-by-case basis between the customer and the utility. Some facilities have successfully completed projects, one of which is the West Boise wastewater treatment plant.

\section{Emissions Regulations/Rules Specific to CHP}

None

Other Barriers or Incentives for CHP

Idaho supports net metering for all projects under $100 \mathrm{~kW}$.

\section{Illinois}

\section{State-Level Financial Incentives}

None

Interconnection Provisions/Net Metering

The PUC is in the process of creating a standardized rule (Cuttica 2002). 


\section{Emissions Regulations/Rules Specific to CHP}

None. Generators less than $1 \mathrm{MW}$ are not required to get an air permit.

The Commerce Commission has been looking into regulations regarding CHP since 1999.

\section{Indiana}

\section{State-Level Financial Incentives}

For information on the following programs, see http://www.state.in.us/doc/energy/index.html. Industrial Energy Efficiency Fund provides a loan for production of equipment that will result in significant energy savings.

Distributed Generation Grant Program and the Alternative Power and Energy Grant Program provide funds for high-efficiency cogeneration systems, alternative energy technologies, and infrastructure (Rogers 2003).

\section{Interconnection Provisions/Net Metering}

The Indiana Utility Regulation Commission is in the process of deciding on a policy and in 2003 will issue rules for future tariffs. The state currently has cogeneration rules that cover interconnection in response to PURPA (Rogers 2003).

Emissions Regulations/Rules Specific to CHP

None

\section{Other Barriers or Incentives for CHP}

All utilities design their own stand-by tariffs and exit fees.

\section{Iowa}

\section{State-Level Financial Incentives}

None

\section{Interconnection Provisions/Net Metering}

Neither the Iowa Utilities Board nor the state of Iowa has a uniform policy for CHP interconnection. CHP facilities do need to meet the requirements of a PURPA QF.

\section{Emissions Regulations/Rules Specific to CHP}

None

\section{Kansas}

\section{State-Level Financial Incentives}

None

\section{Interconnection Provisions/Net Metering}

None as of yet, but in the 2001-2002 legislative session, the Kansas Legislature had 3 bills related to cogeneration and renewables: HR 2631; HR 2633; and HR 2646. Although none of these bills passed, they are on record for further work. The bills can be found at http://www.kslegislature.org/cgi-bin/bills/index.cgi (Barnes 2002).

\section{Emissions Regulations/Rules Specific to CHP}

None 


\section{Kentucky}

State-Level Financial Incentives

None

\section{Interconnection Provisions/Net Metering}

Each utility has a tariff in effect for customer-generated power. The agreements are done on a case-by-case basis for each project.

By order of the PSC in March 2002, utilities must make net metering available for renewable projects less than $10 \mathrm{~kW}$ residential or $25 \mathrm{~kW}$ non-residential, for up to 25 customers during a three-year pilot program (Shaw 2003).

\section{Emissions Regulations/Rules Specific to CHP}

None

\section{Other Barriers or Incentives for CHP}

Within the PSC is the State Board on Electric Generation and Distribution Siting. A merchant system that does not exceed $150 \mathrm{MW}$, is located at a manufacturer's plant, and uses steam from the cogen facility in the manufacturing process is exempt (Young 2003).

\section{Louisiana}

\section{State-Level Financial Incentives}

None. There is not a registry of cogeneration facilities that would allow for communication between a company producing steam and a company requiring it.

\section{Interconnection Provisions/Net Metering}

Utilities are required to buy at their avoided cost (McGee 2002). In response to PURPA, the PSC gave a general order (U-14964) and an update (U-22739) that defined avoided cost in the state.

\section{Emissions Regulations/Rules Specific to CHP}

None

\section{Other Barriers or Incentives for CHP}

Louisiana has long used CHP — an adequate amount of electricity was not available in the state, so companies generated their own. This ended when electricity companies convinced businesses that they could buy electricity cheaper than they could produce it. Also in Louisiana, there are production facilities that require more steam than electricity, and sometimes they are partnered with the nearby utility for CHP (McGee 2002).

\section{Maine}

\section{State-Level Financial Incentives}

None

\section{Interconnection Provisions/Net Metering}

The Maine PUC adopted "Chapter 360: Cogeneration and Small Power Production" into their regulations for facilities less than $80 \mathrm{MW}$. The chapter is available at $\mathrm{ftp}: / / \mathrm{ftp}$. state.me.us/pub/sos/cec/rcn/apa/65/407/407c360.doc. In this order, only $25 \%$ of the total energy input can be coal, natural gas, or oil. The remainder must come from a renewable source. 
In February of 2003, the state enacted Sec. 1, 35-A MRSA c.31, sub-c, 6-A: Distributed Generation. Among other things, this order tasked the Public Utility Commission to complete a rulemaking process for net metering and interconnection that ensures the reliability and safety of the grid while not creating unreasonable barriers for distributed generation.

\section{Emissions Regulations/Rules Specific to CHP}

None

\section{Maryland}

\section{State-Level Financial Incentives}

None

Interconnection Provisions/Net Metering

None

\section{Emissions Regulations/Rules Specific to CHP}

None

\section{Massachusetts}

\section{State-Level Financial Incentives}

None

\section{Interconnection Provisions/Net Metering}

Massachusetts Order 220CMR 8 regulates the interconnection of qualified facilities under PURPA. This document is available at http://www.state.ma.us/dpu/electric/99-

38/220finalreg.htm.

In 2002, the Massachusetts Department of Telecommunications and Energy (DTE) issued an order (02-38-a) to establish a DG Collaborative forum. In March 2003, Distributed Generation Interconnection Collaborative (DGC) submitted proposed standards to the DTE outlining simplified (for qualified facilities on a radial network), expedited (for certified facilities), and standard interconnection. Simple and expedited are proposed, including the "radial network only" provision (DGC 2003a). The proposal is currently under review by the DTE.

Massachusetts General Legislature Chapter 164, §1G(g); Dept. of Tel. and Energy 97-111, allows for net metering of qualifying facilities under $60 \mathrm{~kW}$.

\section{Emissions Regulations/Rules Specific to CHP}

The Massachusetts electricity restructuring legislation directs the Department of Environmental Protection to develop an output-based standard for any pollutant determined to be of concern to public health and also to implement at least one such standard in 2003 (ENN 2001). In April of 2003, DEP proposed changes to the NOx Allowance Trading Program that would credit energy efficient and renewable energy projects for energy saved (Mass. DEP 2003). DEP is now reviewing public comments.

Massachusetts is awaiting the finalized RAP rule for review (Weston 2002). 


\section{Other Barriers or Incentives for CHP}

DGC also submitted a proposed interconnection tariff model to the DTE in May 2003 (DGC 2003b).

\section{Michigan}

\section{State-Level Financial Incentives}

Though it does not specifically mention CHP or DG in its authorizing legislation, the Michigan Energy-Efficiency Fund has helped finance several CHP projects.

\section{Interconnection Provisions/Net Metering}

Michigan's interconnection standards are outlined in Case 12485. A summary of this case can be found at http://efile.mpsc.cis.state.mi.us/cgi-bin/efile/viewcase.pl?casenum=12485. Onsite generation is also covered at http://www.michiganlegislature.org/law/GetObject.asp?objName=460-10a.

\section{Emissions Regulations/Rules Specific to CHP}

None

\section{Other Barriers or Incentives for CHP}

Utility customers in Michigan that provide their own power are exempt from exit fees.

\section{Minnesota}

\section{State-Level Financial Incentive}

None

\section{Interconnection Provisions/Net Metering}

CHP facilities of less than $40 \mathrm{~kW}$ receive retail rate for excess electricity generated through a net metering law.

In 2003, the Department of Commerce submitted the results of their working group on DG to the Public Utilities Commission (Minn. DOC 2003). The report covers technical standards as well as tariff models for incorporating DG into the electricity mix.

\section{Emissions Regulations/Rules Specific to CHP}

All facilities follow the normal generator process for the requirement of an air quality permit. CHP facilities smaller than $5 \mathrm{MW}$ are exempt from further environmental review. For facilities between 25 and $50 \mathrm{MW}$, the Environmental Quality Board is required to prepare an Environmental Assessment worksheet. An environmental impact statement and a site permit are required for facilities greater than $50 \mathrm{MW}$ (Haase 2002).

\section{Missouri}

\section{State-Level Financial Incentives}

Large utilities allow a peaking credit for large CHP facilities where generators are notified a day ahead what price they can receive from the utility for power supplied to the grid the next day. These CHP facilities enter into a prior agreement with the utility.

No other state programs are currently available. 
Interconnection Provisions/Net Metering

Individual utilities determine interconnection guidelines.

Emissions Regulations/Rules Specific to CHP

None

Mississippi

State-Level Financial Incentives

None

Interconnection Provisions/Net Metering

Individual utilities determine interconnection guidelines.

Emissions Regulations/Rules Specific to CHP

None

Montana

State-Level Financial Incentives

None

Interconnection Provisions/Net Metering

Individual utilities determine interconnection guidelines.

Emissions Regulations/Rules Specific to CHP

None

Nebraska

State-Level Financial Incentives

None

Interconnection Provisions/Net Metering

Because all power suppliers in Nebraska are publicly owned, they would individually set any interconnection guidelines. Rates and tariffs are set by the public body responsible for setting policy for power suppliers. Any power-producing facility in the state must be reviewed prior to construction by the Power Review Board according to standards set in the Nebraska Revised Stature Section 70-1014.

Emissions Regulations/Rules Specific to CHP

None

Nevada

State-Level Financial Incentives

None

Interconnection Provisions/Net Metering

Individual utilities determine interconnection guidelines. 


\section{Emissions Regulations/Rules Specific to CHP}

None

\section{New Hampshire}

\section{State-Level Financial Incentives}

None

Interconnection Provisions/Net Metering

Individual utilities determine interconnection guidelines.

\section{Emissions Regulations/Rules Specific to CHP}

None

This state is designing a $\mathrm{NO}_{\mathrm{x}}$ trading program that takes the benefits of $\mathrm{CHP}$ into account.

\section{New Jersey}

\section{State-Level Financial Incentives}

New Jersey has a tax credit for the purchase of cogeneration equipment (Bozzo 2002) and a release on gas tax for fuel that is to be used in cogeneration (Brown et al. 2002).

\section{Interconnection Provisions/Net Metering}

Regulated by utilities.

\section{Emissions Regulations/Rules Specific to CHP}

None

\section{New Mexico}

\section{State-Level Financial Incentives}

None

\section{Interconnection Provisions/Net Metering (Wentz 2003)}

Standard guideline developed by PUC in NMPRC Rule 570 in response to PURPA. Energy from qualifying facilities is paid for at the average economy energy price for that month. If dependable capacity is available to the utility, the qualifying facility must negotiate with the utility for the sale of that power.

Net metering for projects less than $10 \mathrm{~kW}$.

\section{Emissions Regulations/Rules Specific to CHP}

None

\section{New York}

\section{State-Level Financial Incentives}

The New York State Energy Research and Development Authority funds the Power Systems Program that has strived over the last 2 years to promote emerging DG technologies. Eighty percent of the program funding has been allotted to CHP demonstration programs. In exchange for being allowed to showcase the technology, NYSERDA co-funds the project. Details can be found at http://www.nyserda.org/transportation/powersystems.html. 
Order No. 00-E-0005 (see http://www.dps.state.ny.us/fileroom/doc10691.pdf ) required the PUC to run the Distributed Generation Pilot Program. This is a 3-year pilot program that began in 2000, which will assist the utilities in planning for DG.

The New York PSC has implemented a gas tax exemption for self-generation.

\section{Interconnection Provisions/Net Metering}

The PSC has revised guidelines for interconnection, which are available at http://www.dps.state.ny.us/94e0952_11152000.pdf. These guidelines are under revision now in an attempt to streamline them based on lessons learned (Worden 2002). The largest utility that does not fall under the jurisdiction of the PSC is the Long Island Power Authority (LIPA). It uses the PSC interconnect guidelines, but the PSC does not receive feedback from the authority on them.

\section{Emissions Regulations/Rules Specific to CHP}

The New York Department of Environmental Conservation (DEC) is currently under state order to revise emissions standards for DG. This process has been in process since 2000, and DEC is currently working on a white paper describing options. This is largely based on California, Texas, and RAP output-based standards (Smith 2002).

The state just closed a comment period for draft standards that were released in May 2003.

\section{Other Barriers or Incentives for CHP}

The PSC issued order 99-E-1470 utility tariffs and fair treatment of DG and CHP (NY PSC 2001).

\section{North Carolina}

\section{State-Level Financial Incentives}

The Avoided Costs Program and the Green Power Program

\section{Interconnection Provisions/Net Metering}

Utilities determine interconnection standards.

\section{Emissions Regulations/Rules Specific to CHP}

None

\section{North Dakota}

\section{State-Level Financial Incentives}

None

Interconnection Provisions/Net Metering

For facilities less than $100 \mathrm{~kW}$, monthly energy is purchased at avoided cost.

\section{Emissions Regulations/Rules Specific to CHP}

None

\section{Ohio}

\section{State-Level Financial Incentives}

None 


\section{Interconnection Provisions/Net Metering}

PUC has authored standards for interconnection.

Emissions Regulations/Rules Specific to CHP

None

\section{Oklahoma}

\section{State-Level Financial Incentives}

None

\section{Interconnection Provisions/Net Metering}

The commission has a rule in response to PURPA. The interconnection issue is under discussion at the commission.

Net metering for facilities less than $100 \mathrm{~kW}$ and 25,000 kWh/year.

\section{Emissions Regulations/Rules Specific to CHP}

None

\section{Oregon}

\section{State-Level Financial Incentives}

None

Interconnection Provisions/Net Metering

None, except under PURPA. PURPA QFs receive prices based on avoided costs.

\section{Emissions Regulations/Rules Specific to CHP}

None

Pennsylvania

\section{State-Level Financial Incentives}

None

\section{Interconnection Provisions/Net Metering}

Pennsylvania uses the PJM interconnection LLC interconnection agreement. Guidelines can be found at http://www.pjm.com.

\section{Emissions Regulations/Rules Specific to CHP}

In 2001, the Department of Environmental Protection (see http://www.dep.state.pa.us) released a resolution to create a larger market for DG. This includes a more rapid permitting process for clean DG. This resolution can be found at http://www.dep.state.pa.us/dep/subject/advcoun/aqtac/2001/may/res01-1.pdf.

\section{Rhode Island}

\section{State-Level Financial Incentives}

None

Interconnection Provisions/Net Metering

CHP facilities that wish to sell power to the grid must be registered power producers with the 
New England Power Pool and sign an interconnection agreement with the local utility. CHP facilities that sell power are listed at http://www.ripuc.org.

Emissions Regulations/Rules Specific to CHP

None

\section{South Carolina}

State-Level Financial Incentives

None

Interconnection Provisions/Net Metering

Utilities negotiate interconnections with customers.

Emissions Regulations/Rules Specific to CHP

None

\section{South Dakota}

State-Level Financial Incentives

Only for renewable energy.

Interconnection Provisions/Net Metering

Utilities have tariffs that are approved by PUC.

Emissions Regulations/Rules Specific to CHP

None

\section{Tennessee}

State-Level Financial Incentives

None

Interconnection Provisions/Net Metering

TVA has interconnection standards for its territory.

Emissions Regulations/Rules Specific to CHP

None

\section{Texas}

State-Level Financial Incentives

The Texas emissions for CHP regulations are often viewed as an incentive to use CHP.

\section{Interconnection Provisions/Net Metering}

PUC began investigating DG in 1998 in an effort to fend off an anticipated capacity shortfall in 1999 and 2000. In 1999, PUC published an Interconnect Handbook. The updated 2003 handbook is available at http://www.puc.state.tx.us/electric/projects/21965/dgmanual.pdf. This includes technical guidelines, as well as implementation guidelines.

\section{Emissions Regulations/Rules Specific to CHP}

The Texas Natural Resources Conservation Commission has an exception for CHP in its air quality requirements (TNRCC 2001, available at 
http://www.tnrcc.state.tx.us/permitting/airperm/nsr_permits/files/segu_permitonly.pdf). These requirements allow for a credit to be given to generators using $\overline{C H P}$, in an effort to encourage the use of CHP in the state.

Utah

\section{State-Level Financial Incentives}

None

Interconnection Provisions/Net Metering

Utilities negotiate interconnections on an individual basis with installers. CHP facilities sell power to the grid at the avoided cost rate up to $1 \mathrm{MW}$.

Emissions Regulations/Rules Specific to CHP

None

Vermont

State-Level Financial Incentives

None

Interconnection Provisions/Net Metering

The utility commission is discussing a standardized interconnection rule.

Emissions Regulations/Rules Specific to CHP

None

\section{Virginia}

\section{State-Level Financial Incentives}

None

Interconnection Provisions/Net Metering

None

Emissions Regulations/Rules Specific to CHP

None

\section{Other Barriers or Incentives for CHP}

The Department of Environmental Quality (DEQ) has organized a series of stakeholder meetings over 2003 in order to outline the barriers to DG and to explore opportunities for incentives to encourage DG in the state.

\section{Washington}

\section{State-Level Financial Incentives}

None

Interconnection Provisions/Net Metering

Utilities negotiate interconnections with customers. 


\section{Emissions Regulations/Rules Specific to CHP}

None

Other Barriers or Incentives for CHP

None currently, but the state used to offer a cogeneration equipment sales tax break.

\section{West Virginia}

\section{State-Level Financial Incentives}

None

Interconnection Provisions/Net Metering

Interconnection in West Virginia follows PJM interconnection standards.

\section{Emissions Regulations/Rules Specific to CHP}

None

\section{Wisconsin}

\section{State-Level Financial Incentives}

Provision Wisconsin Statute 196.025(4) of Wisconsin Act 9 required PSC to develop an incentive program for small-scale electricity generators (PSCW 2001).

\section{Interconnection Provisions/Net Metering}

The Wisconsin Distributed Resources Collaborative (WiDR) has been formed and charged by PSC to develop interconnection standards for the state. These standards are in draft form and are available at http://www.wisconsindr.org.

\section{Emissions Regulations/Rules Specific to CHP}

None

\section{Wyoming}

\section{State-Level Financial Incentives}

None

\section{Interconnection Provisions/Net Metering}

Utilities in the state negotiate interconnection on an individual basis with customers. There is a net metering provision for systems under $25 \mathrm{~kW}$ (IREC 2001).

Emissions Regulations/Rules Specific to CHP

None 